Original article / Оригинальная статья

УДК 551.242

DOI: http://dx.doi.org/10.21285/2686-9993-2019-42-4-425-436

\title{
Clockwise rotation of the Tarim basin driven by the Indian plate impact
}

\author{
(c) Junmeng Zhao a, Peizhen Zhang ${ }^{b}$, Xiaohui Yuanc, Weijun Gand, \\ Jimin Sun ${ }^{e}$, Tao Deng ${ }^{f}$, Robert van der Hilstg, Xiankang Zhang ${ }^{\mathrm{h}}$, Hongbing Liui, \\ Xiaoping Yangi, Maodu Yang ${ }^{k}$, Qiang Xu', Hen' ${ }^{g}$ Zhang $^{\mathrm{m}}$, Gong Deng ${ }^{\mathrm{n}}$, Changhui Ju${ }^{\circ}$, \\ Jiyang Lin ${ }^{p}$, Jiwen Teng ${ }^{q}$ \\ a,i,k,l,m,n,o|nstitute of Tibetan Plateau Research, Chinese Academy of Sciences, Beijing, China \\ 'Sun Yet-sen University, Guangzhou, China \\ 'Deutsches GeoForschungsZentrum, Potsdam, Germany \\ d.jnstitute of Geology of China Earthquake Administration, Beijing, China \\ e,q|nstitute of Geology and Geophysics, Chinese Academy of Sciences, Beijing, China \\ Institute of Vertebrate Paleontology and Paleoanthropology, Chinese Academy of Sciences, Beijing, China \\ Massachusetts Institute of Technology, Cambridge, United States of America \\ h,p Center for Geophysical Exploration of China Earthquake Administration, Zhengzhou, China
}

\begin{abstract}
Tarim basin is usually regarded as a rigid tectonic block that resists the northward expansion of the Tibetan plateau that is associated with ongoing northward motion of the Indian plate. The structural complexity of its tectonic boundaries with adjacent units inferred from seismological studies suggests, however, that this simple view of a static block under north-south compression needs revision. Here, we demonstrate (from Global Position System data) that Tarim basin is rotating clockwise (at a rate of $0.461^{\circ} / \mathrm{Myr}$ ) around a (virtual) vertical axis within the unit. This rotation logi-cally results from the asymmetric nature of the India-Asia collision zone as inferred from seismological studies and can explain the otherwise puzzling pattern of lithospheric interactions along the Tarim basin borders as well as the diachro-nous seawater retreat and the closing of the westerly moisture pathway that results in aridification and desertification of Tarim.
\end{abstract}

Keywords: Tarim Basin, block rotation, Indian plate, Eurasian plate, continental collision, paleoenvironment, westerly moisture pathway

Information about the article: Received October 15, 2019; accepted for publication November 19, 2019; available online December 30, 2019.

For citation: Zhao Junmeng, Zhang Peizhen, Yuan Xiaohui, Gan Weijun, Sun Jimin, Deng Tao, et al. Clockwise rotation of the Tarim basin driven by the Indian plate impact. Earth sciences and subsoil use. 2019;42(4):425-436. https://doi.org/10.21285/2686-9993-2019-42-4-425-436

\section{Вращение Таримского бассейна по часовой стрелке под влиянием движения Индийской плиты}

\author{
(c) Цзюньмэн Чжао ${ }^{a}$, Пэйчжэнь Чжан ${ }^{b}$, Сяохуй Юаньс, Вэйцзюнь Гань

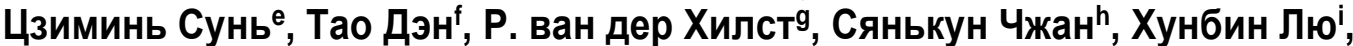 \\ Сяопин Янј, Маоду Ян ${ }^{\mathrm{k}}$, Цян Сюй', Хэн Чжан ${ }^{\mathrm{m}}$, Гун Дэн ${ }^{\mathrm{n}}$, Чанхуй Цзюйо, \\ Цзиян Линь ${ }^{p}$, Цзивэнь Тэн ${ }^{q}$ \\ a.,,k,l,m,n,o Институт изучения Тибетского плато, Китайская академия наук, г. Пекин, Китай \\ ьуниверситет Сан Ейт-сен, г. Гуанджоу, Китай \\ сНемецкий ГеоФоршунгЦентр, г. Потсдам, Германия \\ d.,Институт геологии Сейсмологического бюро Китая, г. Пекин, Китай \\ е,qИнститут геологии и геофизики, Китайская академия наук, г. Пекин, Китай \\ †Институт позвоночных, палеонтологии и палеоантропологии, Китайская академия наук, г. Пекин, Китай \\ 9Массачусетский технологический институт, г. Кембридж, Соединенные Штаты Америки \\ h,pЦентр геофизических исследований Сейсмологического бюро Китая, г. Чжэнчжоу, Китай
}

Резюме: Таримский бассейн обычно рассматривается как тектонический выступ, препятствующий продвижению Тибетского плато на север, в соответствии с продолжающимся движением на север Индийской плиты. Однако структурная сложность его тектонических границ, установленная на основе сейсмологических 
исследований, дает основание считать, что этот упрощенный взгляд, предполагающий простое движение Таримского бассейна в результате меридионального сжатия статического блока, нуждается в пересмотре. Наши данные позволяют продемонстрировать в Глобальной системе координат, что Таримский бассейн вращается по часовой стрелке со скоростью 0,461 в миллион лет вокруг виртуальной оси внутри структуры. Это вращение логически вытекает из асимметричной природы зоны Индо-Азиатского столкновения, которая установлена в процессе сейсмологических исследований, призванных объяснить загадочную картину литосферных взаимодействий вдоль границ Тарима, а также изучения диахронного отступления границы моря и перекрытия западного канала доступа морской воды, что привело к аридизации и опустыниванию Таримского бассейна.

Ключевые слова: Таримский бассейн, вращение блока, Индийская плита, континентальная коллизия, палеогеографические реконструкции, западный морской канал

Информация о статье: Дата поступления 15 октября 2019 г.; дата принятия к печати 19 ноября 2019 г.; дата онлайн-размещения 30 декабря 2019 г.

Для цитирования: Чжао Цзюньмэн, Чжан Пэйчжэнь, Юань Сяохуй, Гань Вэйцзюнь, Сунь Цзиминь, Дэн Тао [и др.]. Вращение Таримского бассейна по часовой стрелке под влиянием движения Индийской плиты. Науки о Земле и недропользование. 2019. Т. 42. № 4. С. 425-436. https://doi.org/10.21285/2686-9993-2019-42-4-425-436

The Tarim basin is a cratonic block located between the Siberian craton and the Tibetan / Pamir plateau, bounded on all sides by major faults and mountain belts (Fig. 1). Its Precambrian basement is covered by thick Paleozoic-Mesozoic-Cenozoic marine sediments and post-Miocene Taklimakan Desert eolian dune sands [1,2]. In the classical view the basin (backstopped by Siberia) resists the northward motion of the Tibetan plateau caused by the IndiaAsia collision [3], with minor rotations of the basin around Euler poles outside the unit [4, 5]. Seismological studies of Tarim basin boundaries suggest, however, that lithospheric interactions with surrounding units are more complicated than expected from this canonical model. Changes in environment, such as the Paleogene aridification and desertification, attributed to a combination of Tibetan Plateau uplift and seawater retreat from the area [6], also suggest higher order complexity. Here we report evidence from Global Position System (GPS) data for clockwise rotation of the Tarim block around a virtual axis within the unit, yielding larger strain gradients than predicted previously from paleomagnetic data. This rotation explains the observed structural complexity along the boundaries, as well as changes in paleoenvironment, and is itself a logical consequence of the asymmetry and diachronous nature of the India-Asia collision zone. Over the past two decades a number of seismic experiments have been conducted across the borders of Tarim basin (Fig. 1) with the purpose of studying the lithospheric structure of the basin with respect to the surrounding mountain belts. Details about the experiments are given in the Online Supplement; here we summarize the results insofar they are relevant for the discussion of regional variations in deformation style. In the north, the observation of a double Moho beneath Tien Shan and joint inversion of seismic, gravity, and geomagnetic data suggest that Tarim basin crust underthrusts central Tien Shan [7] (Line XB; Fig. 2, a). In the northeast, the seismic data reveal southward underthrusting of the Junggar basin lower crust beneath Tien Shan and a gap between the Moho of Tarim basin and eastern Tien Shan (Line KJ; Fig. 2, b). In the southeast, wide-angle reflection/refraction and joint inversion with gravity data reveal southward underthrusting of the Tarim lithosphere beneath the Altyn Shan and Tibet [8] (Line BD; Fig. 2, c). In the southwest, pure shear deformation is accommodated by deep faults and receiver function profiles reveal a Moho step of $\sim 20 \mathrm{~km}$, from $\sim 80 \mathrm{~km}$ beneath Tibet to $\sim 60 \mathrm{~km}$ beneath Tarim [9, 10] (Line ANTILOPE-I; Fig. 2, d).

Starting at the northern part of the Tarim Basin and ending at the northern margin of the Junggar Basin, the XB Line crosses northern Tarim Basin, the Tien Shan, and the Junggar Basin, with a length of $900 \mathrm{~km}$. Along the profile, wide-angle seismic reflection/refraction and a joint inversion of gravity 
and geomagnetism have been carried out. The results indicate that the Tarim Basin is underthrusting the Tien Shan [7] and a double Moho structure beneath the Tien Shan has been observed (Fig. 2, a).

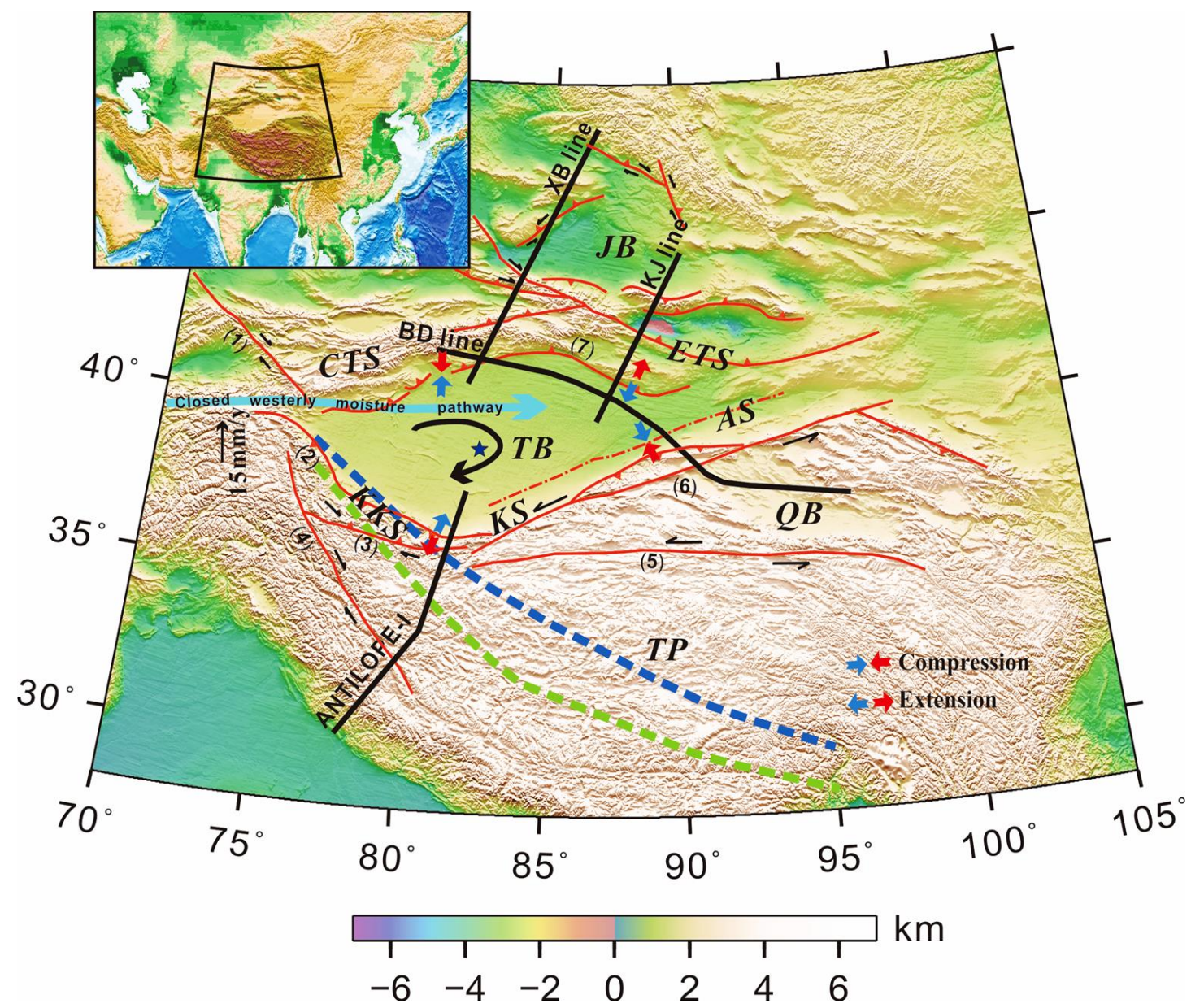

Fig. 1. Map of Tarim Basin and surrounding Tibetan and Tien Shan orogenic belts

Solid lines show locations of the profiles. Dashed lines indicate the front of the Indian mantle lithosphere seen by seismic tomography and receiver functions (green line denotes [11] and blue line denotes [10].

Thin red lines denote main faults around the Tarim Basin. Black triangle pairs indicate compression or extension.

Blue start denotes the Euler pole, around which the Tarim block is rotating clockwisely

Abbreviations for tectonic units: TB - Tarim Basin; JB - Junggar Basin;

CTS - Central Tien Shan; ETS - Eastern Tien Shan; AS - Altyn Shan;

KS - Kunlun Shan; KKS - Karakoram Shan; QB - Qaidam Basin; TP - Tibetan plateau

Numbered faults: 1 - Talas-Fergana Fault; 2 - West Kunlun Piedmont Fault;

3 - Kangxiwar Fault; 4 - Miya-Tianshendaban Fault; 5 - East Kunlun Fault; 6 - Altyn Fault; 7 - Tarim Northern Margin Fault

Puc. 1. Карта Таримского бассейна и прилегающих к нему территорий Тибета и Тяньшанских орогенических поясов

Сплошными линиями показано положение профилей. Пунктирными линиями отмечена передняя часть литосферной мантии по данным сейсмической томографрии и функций сейсмоприемника (зеленая линия - по данным источника [11] и синяя - по данным источника [10]. Тонкими красными линиями отмечены главные разломы вокруг Таримского бассейна. Черные стрелки указывают направление сжатия или растяжения. Синей звездой отмечен полюс Эйлера, вокруг которого Таримский блок вращается по часовой стрелке

Сокращения для тектонических единиц: ТВ - Таримский бассейн; JB - Джунгарский бассейн;

CTS - Центральный Тянь-Шань; ETS - Восточный Тянь-Шань; AS - Алтын Шань; KS - Куньлунь Шань; KS - Кунлун Шань; KKS - Каракорум Шань; QB - бассейн Кайдам; TP - Тибетское плато Пронумерованные разломы: 1 - Таласо-Ферганский; 2 - Западно-Куньлунский;

3 - Разлом Канксивар; 4 - Мия-Таньшендабан; 5 - Восточно-Куньлунский; 6 - Разлом Алтын; 7 - Разлом северной границы Тарима 

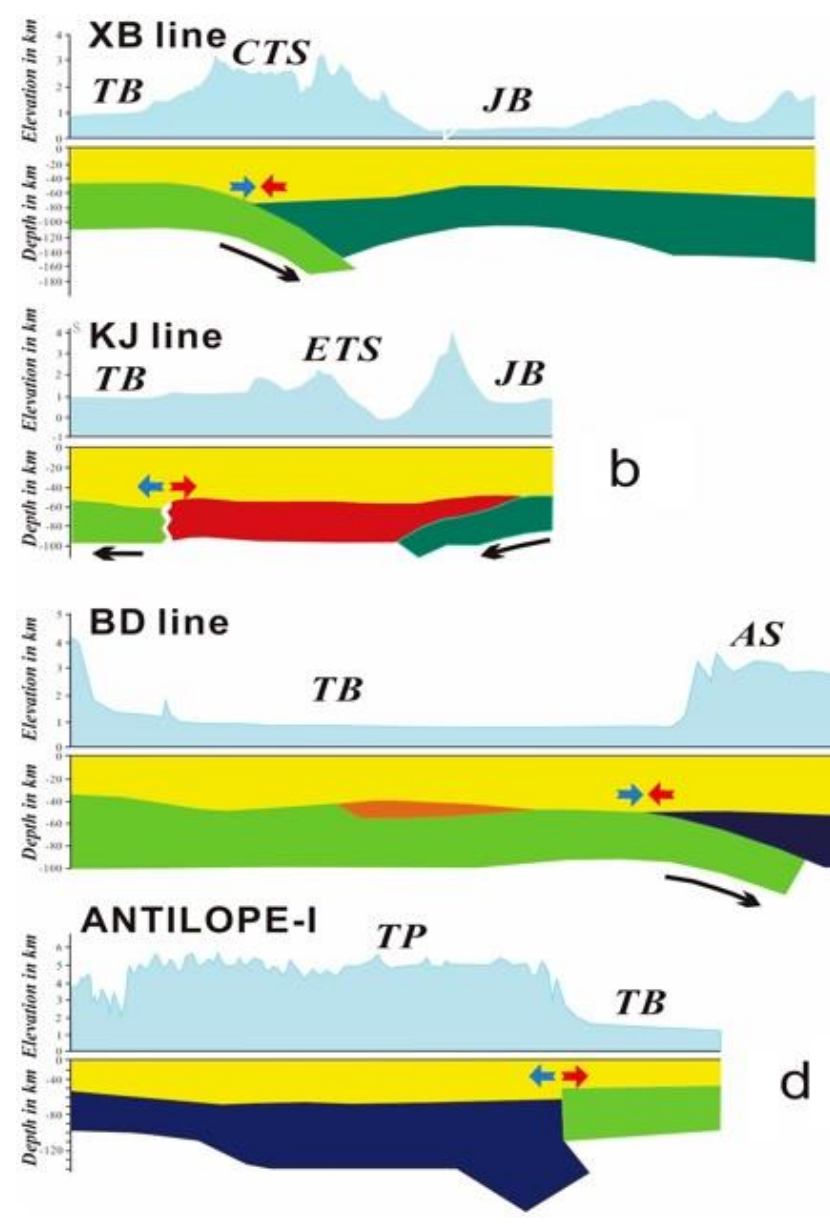

Fig. 2. Cartoons showing interaction of crust and mantle lithosphere between Tarim block and the surroundings orogenic belts Along four profiles shown in Fig. 1

The crust is homogeneously indicated by yellow color, while mantle lithospheres of different units are denoted by different colors: green - Tarim Basin; cyan - Jungar Basin; red - Tien Shan; blue - Tibetan Plateau

Abbreviations are the same in Fig. 1

Pис. 2. Цветные иллюстрации, показывающие взаимодействие коры и мантийной литосферы между Таримским блоком и окружающими его орогенными поясами

Соответствуют четырем профиилям, показанным на рис. 1

Земная кора обозначена желтым цветом, а мантийная литоссрера для разных структур показана разными иветами: зеленым - под Таримским бассейном, голубым - под Джунгарским, красным - под Тянь-Шанем, синим - под Тибетским плат

Сокращения те же, что на рис. 1.

The recent $600-\mathrm{km}$ long seismic profile (KJ line) crosses the northeastern margin of the Tarim Basin, the east Tien Shan and the southern part of the Junggar Basin. This comprehensive geophysical profile reveals a double-Moho structure underneath the northern margin of the east Tien Shan with underthrusting of the Junggar Basin lower crust beneath the Tien Shan (Fig. 2, b). Beneath the southern Tien Shan margin a gap exists between the Moho of the Tarim Basin and that of the east Tien Shan
(Fig. 2, b). Along with previous seismic profiles this reveals a complex configuration along the basin boundaries. The NW-SE striking, 1400-km long seismic profile (BD Line) traverses the eastern part of the Tarim Basin, the Altyn Shan, and the Qaidam Basin. Wide-angle reflection/refraction and joint inversion of gravity and geomagnetism revealed an underthrusting of the Tarim lithosphere beneath the Altyn Shan to a depth of $90 \mathrm{~km}$ [8] (Fig. 2, c). The ANTILOPE-I is a passive-source seismic profile, located in 
western Tibet, extending from Himalaya to the southern Tarim Basin, with a total length of $\sim 800 \mathrm{~km}$. The Moho is seen at a depth of $\sim 80 \mathrm{~km}$ underneath Tibet and suddenly shallows to $\sim 60 \mathrm{~km}$ underneath the Tarim Basin with a step of $20 \mathrm{~km}[10]$. Close to the profile a Sino-French experiment revealed a similar Moho step beneath the Altyn Shan [9]. The crustal shortening here is accommodated by pure shear in contrast to simple shear at the southern Tarim margin (along BD line) (Fig. 2, d).

The lithospheric interactions between bounding units implied by these observations are inconsistent with the canonical framework of predominantly NS compression but are readily explained if the strain gradients due to clockwise rotation of the Tarim Block are larger than previously suggested. Paleomagnetic data suggest negligible post-Cretaceous rotation of Tarim basin [4], whereas a kinematic model derived from modeling slip rates along major thrust and strike-slip faults revealed a Cenozoic clockwise rotation of the Tarim basin with respect to Siberia at a rate of $0.65 \pm 0.3^{\circ} / \mathrm{Mys}$ and around a pole at $\left(43.5^{\circ} \mathrm{N}, 95.7^{\circ} \mathrm{E}\right)[5]$. Euler poles outside Tarim produce rotations that are too small, however, to explain the different deformation styles inferred from the seismological studies.

GPS measurements constrain present-day surface motions around the Tarim basin. In a reference frame of stable Eurasian plate (Fig. 3, a) GPS vectors in the western Tarim regions are dominated by $\mathrm{N}$ $S$ direction while eastern Tarim moves toward the NE. From GPS data [12] we calculated the relative motion of Tarim basin with respect of its surrounding areas (Fig. $3, b$ ). First, we solved for the Euler vector that minimized the RMS velocity of all these surrounding stations. Then, through reverse rotation of the GPS velocity field around the Euler vector thus obtained we removed the overall rigid rotation of the surrounding units. The resulting "Tarim fixed reference frame" highlights the clockwise rotation of the Tarim basin with respect to its surroundings. The rotation rate $\left(0.461 \pm 0.036^{\circ} / \mathrm{Myr}\right)$ is close to the inference from kinematic data by Avouac et al. [5], but a pole within the Tarim basin (at $39.2^{\circ} \pm 0.27^{\circ} \mathrm{N}, 82.0^{\circ} \pm 0.34^{\circ} \mathrm{E}$ ) produces strain gradients that can explain morphological changes along the Tien Shan [3] as well as the otherwise puzzling styles of deformation in the boundary zones, that is, compression in NW with central Tien Shan, trans-tension in NE with eastern Tien Shan, compression with Altyn Tagh Shan in the SE, and left lateral shear motions in the SW (Fig. 1).

The clockwise rotation of the Tarim block can explain variations in the topography of the Tien Shan. Geographically, the central Tien Shan is north-south symmetric (Fig. 2, a), whereas the eastern Tien Shan is asymmetric (Fig. 2, b). The geometry of the crustal interplay may result in an extension and strike sliding underneath the southern Tien Shan margin. The elevation of the southern Tien Shan is reduced by weathering and erosion, causing asymmetric topography of the Tien Shan along the KJ line. The tectonic difference of the southern and northern Tien Shan, and the deformation of the basins at its two sides are different. At the southern margin of the Junggar Basin, the deformation is strong, causing steep structures and intense folding. The northern margin of the Tarim Basin is relatively flat, because it has experienced less tectonic deformation.

Block rotations are not expected in an overall regime of (pure shear) north-south convergence, but we propose that the rotation of the Tarim basin is driven by the asymmetric indentation of the northward moving Indian plate and facilitated by lateral variations in geomechanical properties of plate boundary zone. First, the lithospheric boundary between the Indian plate and the Eurasian plate beneath Tibet roughly follows a line from the western Tarim basin to the eastern Himalayan syntaxis (Fig. 1) [10, 11]. Second, increased seismic anisotropy [10, 13-15] and high attenuation in the uppermost mantle $[16,17]$ suggest that in central and east Tibet hot and more easily deformable mantle material fills the gap between 


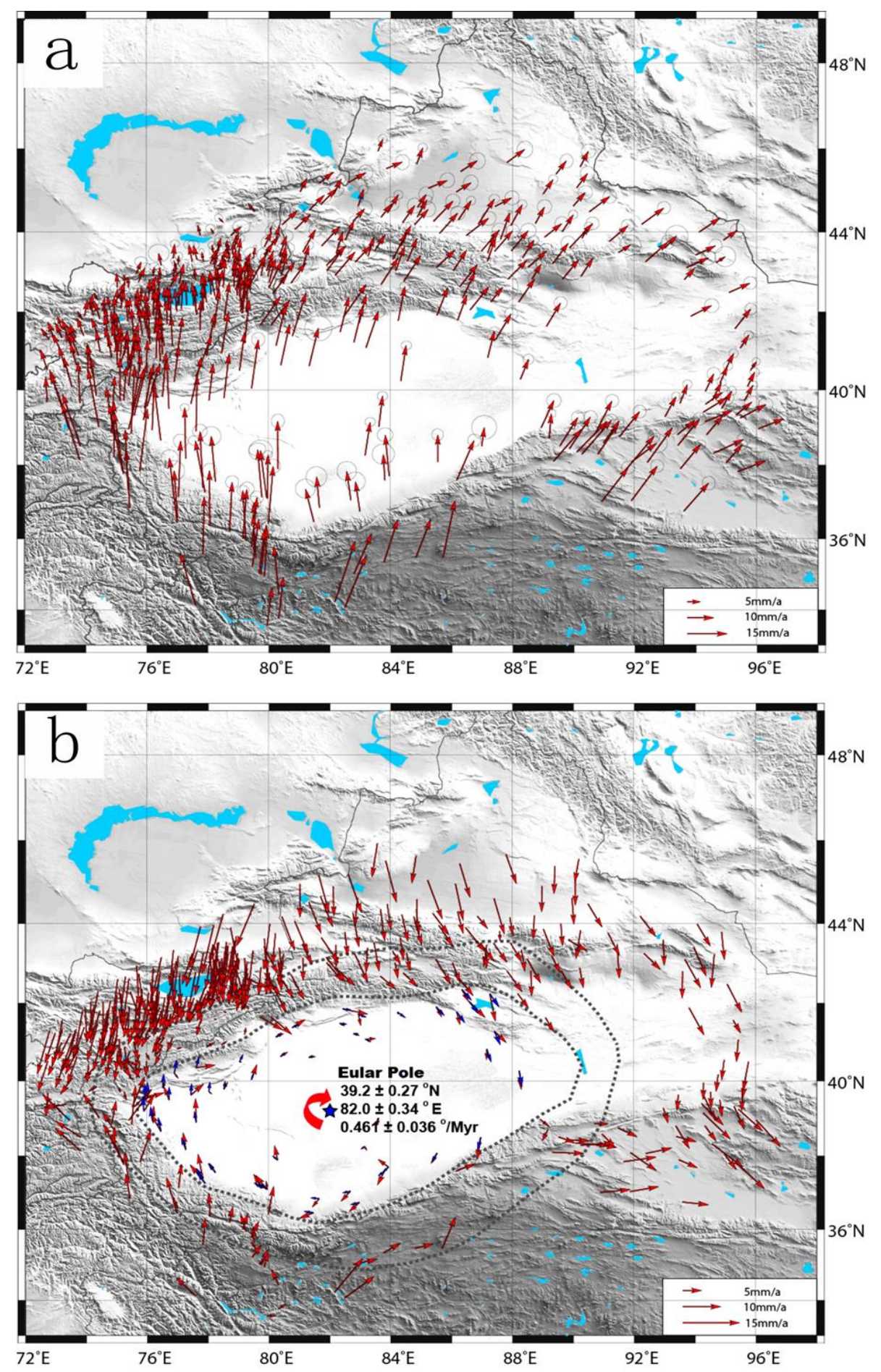

Fig. 3. Observed GPS velocity vectors (red arrows) in and around the Tarim block in a reference frame of Siberia representing the stable Eurasia plate (a); GPS velocity vectors (red arrows) in and around the Tarim block in the "Tarim surrounding vicinity fixed reference frame" (b)

The blue star indicates the Euler pole location of the clockwise rotation of the Tarim block with respect to its surroundings. The blue vectors are modeled GPS velocity

(see text for explanation)

Puc. 3. Наблюдаемые векторы скорости GPS (красные стрелки) внутри и вокруг блока

Тарим в системе отсчета Сибири, представляющей стабильную Евразийскую плиту (а); векторы скорости GPS (красные стрелки) внутри и вокруг блока Тарим

в "Таримском окружающем вицините фиксированной системы отсчета" (b)

Синяя звезда показывает расположение полюса Эйлера для вращения блока Тарим по часовой стрелке относительно его окружения. Синие стрелки показывают смоделированные скорости GPS (пояснения даны в тексте) 
Indian and Asian plates. In western Tibet, toward Pamir, indentation of the Indian plate across the entire width of the Plateau exerts a northward push on the western Tarim basin and the weak zone further east allows the Tarim basin to rotate clockwise in response to the northward push further west.

The rotation of the Tarim block had significant consequences for the paleoenvironment of the Asian interior. Previous studies have indicated that the Northern Pamir has been displaced northward 400-300 km with respect to the rest of Eurasia [18], leading to collision with the southeastern Tien Shan. Traditional views attribute all crustal shortening in this region simply to the northward motion of Pamir in response to the India-Eurasia collision [18]. Our new geophysical evidence refines this view and suggests that the collision of the Northern Pamir with the southern Tien Shan is so localized because the asymmetric indentation of India and the concomitant clockwise rotation of the Tarim Block enhanced the northward displacement of Pamir compared to other parts of the collision zone. The localized convergence influenced the retreat of sea water from the Tarim Basin in the late Eocene $[19,20]$ and accelerated the final collision in the latest Miocene [21-24], which blocked the transport of water-vapor by the prevailing westerlies from the Atlantic and the Mediterranean Sea to the downwind Tarim Basin, leading to the extreme arid climate and the formation of the world secondlargest shifting-sand desert (Taklimakan Desert) in the Tarim Basin in the latest Miocene $[1,25]$.

Block rotation is common in plate boundary zones controlled by strike slip or transpression, but our study indicates that such rotations can also result from asymmetry in the structure and mechanical properties of colliding tectonic units and produce lateral changes in paleoenvironment in predominantly pure shear regimes.

\section{References}

1. Sun JM, Liu TS. The age of the Taklimakan Desert. Science. 2006;312:1621. https://doi.org/10.1126/science.1124616

2. Sun JM, Zhang L, Deng C, Zhu R. Evidence for enhanced aridity in the Tarim Basin of China since 5.3 Ma. Quaternary Science Reviews. 2008;27:10121023. https://doi.org/10.1016/j.quascirev.2008.01.011

3. Avouac JP, Tapponnier P. Kinematic Model of Active Deformation in Central-Asia. Geophysical Research Letters. 1993;20:895-898. https://doi.org/10.1029/93gl00128

4. Chen Y, Cogne JP, Courtillot V. New Cretaceous Paleomagnetic Poles from the Tarim Basin, Northwestern China. Earth and Planetary Science Letters. 1992;114:17-38. https://doi.org/10.1016/0012-821x(92)90149-P

5. Avouac JP, Tapponnier P, Bai M, You H, Wang G. Active thrusting and folding along the northern Tien-Shan and Late Cenozoic rotation of the Tarim relative to Dzungaria and Kazakhstan. Journal of Geophysical Research. Solid Earth. 1993;98:67556804. https://doi.org/10.1029/92jb01963

6. Bosboom R, et al. Linking Tarim Basin sea retreat (west China) and Asian aridification in the late Eocene. Basin Research. 2014;26:621-640. https://doi.org/10.1111/bre.12054

7. Zhao JM, Liu GD, Lu ZX, Zhang XK, Zhao GZ. Lithospheric structure and dynamic processes of the Tianshan orogenic belt and the Junggar basin. Tectonophysics. 2003;376:199-239. https://doi.org/10.1016/j.tecto.2003.07.001

8. Zhao JM, Mooney WD, Zhang X, Li Z, Jin Z, Okaya N. Crustal structure across the Altyn Tagh Range at the northern margin of the Tibetan plateau and tectonic implications. Earth and Planetary Science Letters. 2006;241:804-814. https://doi.org/10.1016/j.epsl.2005.11.003

9. Wittlinger G, Vergne J, Tapponnier $P$, Farra V, Poupinet $G$, Jiang $M$, et al. Teleseismic imaging of subducting lithosphere and Moho offsets beneath western Tibet. Earth and Planetary Science Letters. 2004;221:117-130. https://doi.org/10.1016/S0012-821x(03)00723-4

10. Zhao JM, Yuan X, Liu H, Kumar P, Pei S, Kind $R$, et al. The boundary between the Indian and Asian tectonic plates below Tibet. Proceedings of the National Academy of Sciences of the United States of America. 2010;107:11229-11233. https://doi.org/10.1073/pnas.1001921107

11. Li C, van der Hilst RD, Meltzer AS, Engdahl ER. Subduction of the Indian lithosphere beneath the Tibetan Plateau and Burma. Earth and Planetary Science Letters. 2008;274:157-168. https://doi.org/10.1016/j.epsl.2008.07.016

12. Gan WJ, Zhang P, Shen ZK, Niu Z, Wang $M$, Wan $Y$, et al. Present-day crustal motion within the Tibetan Plateau inferred from GPS measurements. Journal of Geophysical Research. Solid Earth. 2007;112:B08416. https://doi.org/10.1029/2005jb004120 
13. Huang WC, Ni JF, Tilmann F, Nelson D, Guo J, Zhao W, et al. Seismic polarization anisotropy beneath the central Tibetan Plateau. Journal of Geophysical Research. Solid Earth. 2000;105:2797927989. https://doi.org/10.1029/2000JB900339

14. Kind R, Yuan XH. Seismic Images of the Biggest Crash on Earth. Science. 2010;329;14791480. https://doi.org/10.1126/science. 1191620

15. Chen WP, Martin M, Tseng TL, Nowack $\mathrm{RL}$, Hung SH, Huang BS. Shear-wave birefringence and current configuration of converging lithosphere under Tibet. Earth and Planetary Science Letters. 2010;295:297-304. https://doi.org/10.1016/j.epsl.2010.04.017

16. Barazangi $\mathrm{M}$, Ni J. Velocities and Propagation Characteristics of $\mathrm{Pn}$ and $\mathrm{Sn}$ beneath the Himalayan Arc and Tibetan Plateau - Possible Evidence for Underthrusting of Indian Continental Lithosphere beneath Tibet. Geology. 1982;10:179185.

17. Barron J, Priestley K. Observations of frequency-dependent S-n propagation in Northern Tibet. Geophysical Journal International. 2009;179:475-488. https://doi.org/10.1111/j.1365246X

18. Burtman VS, Skobelev SF, Molnar P. Late Cenozoic slip on the Talas-Ferghana fault, the Tien Shan, Central Asia. Geological Society of America Bulletin. 1996;108:1004-1021.

19. Bosboom R, et al. Linking Tarim Basin sea retreat (west China) and Asian aridification in the late Eocene. Basin Research. 2013;26:1-20.
20. Sun JM, Windley BF, Zhang Z, Fu B, Li S. Diachronous seawater retreat from the southwestern margin of the Tarim Basin in the late Eocene. Journal of Asian Earth Sciences. 2016;116:222-231.

21. Fu B, Ninomiya Y, Guo J. Slip partitioning in the northeast Pamir-Tian Shan convergence zone. Tectonophysics. 2010;483:344-364. https://doi.org/10.1016/j.tecto.2009.11.003

22. Sobel ER, Schoenbohm LM, Chen J, Thiede R, Stockli DF, Sudo M, et al. Late MiocenePliocene deceleration of dextral slip between Pamir and Tarim: Implications for Pamir orogenesis. Earth and Planetary Science Letters. 2011;304:369-378. https://doi.org/10.1016/j.epsl.2011.02.012

23. Thompson JA, Burbank DW, Li T, Chen J, Bookhagen B. Late Miocene northward propagation of the northeast Pamir thrust system, northwest China. Tectonics. 2015;34:510-534. https://doi.org/10.1002/2014TC003690

24. Sun JM, Liu W, Liu Z, Deng T, Windley BF, $\mathrm{Fu}$ B. Extreme aridification since the beginning of the Pliocene in the Tarim Basin, western China. Palaeogeography, Palaeoclimatology, Palaeoecology. 2017;485:189-200. https://doi.org/10.1016/j.palaeo.2017.06.012

25. Liu WG, Liu Z, An Z, Sun J, Chang H, Wang $N$, et al. Late Miocene episodic lakes in the arid Tarim Basin, western China. Proceedings of the National Academy of Sciences of the United States of America. 2014;111:16292-16296. https://doi.org/10.1073/pnas.1410890111

\section{Библиографический список}

1. Sun J.M., Liu T.S. The age of the Taklimakan Desert // Science. 2006. Vol. 312. P. 1621. https://doi.org/10.1126/science.1124616

2. Sun J.M., Zhang L., Deng C., Zhu R. Evidence for enhanced aridity in the Tarim Basin of China since $5.3 \mathrm{Ma} / /$ Quaternary Science Reviews. 2008. Vol. 27. P. 1012-1023. https://doi.org/10.1016/j.quascirev.2008.01.011

3. Avouac J.P., Tapponnier P. Kinematic Model of Active Deformation in Central-Asia // Geophysical Research Letters. 1993. Vol. 20. P. 895-898. https://doi.org/10.1029/93gl00128

4. Chen Y., Cogne J.P., Courtillot V. New Cretaceous Paleomagnetic Poles from the Tarim Basin, Northwestern China // Earth and Planetary Science Letters. 1992. Vol. 114. P. 17-38. https://doi.org/10.1016/0012-821x(92)90149-P

5. Avouac J.P., Tapponnier P., Bai M., You H., Wang G. Active thrusting and folding along the northern Tien-Shan and Late Cenozoic rotation of the Tarim relative to Dzungaria and Kazakhstan // Journal of Geophysical Research. Solid Earth. 1993. Vol. 98. P. 6755-6804. https://doi.org/10.1029/92jb01963

6. Bosboom R., et al. Linking Tarim Basin sea retreat (west China) and Asian aridification in the late
Eocene // Basin Research. 2014. Vol. 26. P. 621-640. https://doi.org/10.1111/bre.12054

7. Zhao J.M., Liu G.D., Lu Z.X., Zhang X.K., Zhao G.Z. Lithospheric structure and dynamic processes of the Tianshan orogenic belt and the Junggar basin // Tectonophysics. 2003. Vol. 376. P. 199-239. https://doi.org/10.1016/j.tecto.2003.07.001

8. Zhao J.M., Mooney W.D., Zhang X., Li Z., Jin Z., Okaya N. Crustal structure across the Altyn Tagh Range at the northern margin of the Tibetan plateau and tectonic implications // Earth and Planetary Science Letters. 2006. Vol. 241. P. 804814. https://doi.org/10.1016/j.epsl.2005.11.003

9. Wittlinger G., Vergne J., Tapponnier P., Farra V., Poupinet G., Jiang M., et al. Teleseismic imaging of subducting lithosphere and Moho offsets beneath western Tibet // Earth and Planetary Science Letters. 2004. Vol. 221. P. 117-130. https://doi.org/10.1016/S0012-821x(03)00723-4

10. Zhao J.M., Yuan X., Liu H., Kumar P., Pei S., Kind R., et al. The boundary between the Indian and Asian tectonic plates below Tibet // Proceedings of the National Academy of Sciences of the United States of America. 2010. Vol. 107. P. 11229-11233. https://doi.org/10.1073/pnas.1001921107 
11. Li C., van der Hilst R.D., Meltzer A.S., Engdahl E.R. Subduction of the Indian lithosphere beneath the Tibetan Plateau and Burma // Earth and Planetary Science Letters. 2008. Vol. 274. P. 157168. https://doi.org/10.1016/j.epsl.2008.07.016

12. Gan W.J., Zhang P., Shen Z.-K., Niu Z., Wang M., Wan Y., et al. Present-day crustal motion within the Tibetan Plateau inferred from GPS measurements // Journal of Geophysical Research. Solid Earth. 2007. Vol. 112. P. B08416. https://doi.org/10.1029/2005jb004120

13. Huang W.C., Ni J.F., Tilmann F., Nelson D., Guo J., Zhao W., et al. Seismic polarization anisotropy beneath the central Tibetan Plateau // Journal of Geophysical Research. Solid Earth. 2000. Vol. 105. P. 27979-27989. https://doi.org/10.1029/2000JB900339

14. Kind R., Yuan X.H. Seismic Images of the Biggest Crash on Earth // Science. 2010. Vol. 329. P. 1479-1480. https://doi.org/10.1126/science.1191620

15. Chen W.P., Martin M., Tseng T.-L., Nowack R.L., Hung S.-H., Huang B.-S. Shear-wave birefringence and current configuration of converging lithosphere under Tibet // Earth and Planetary Science Letters. 2010. Vol. 295. P. 297-304. https://doi.org/10.1016/j.epsl.2010.04.017

16. Barazangi M., Ni J. Velocities and Propagation Characteristics of $\mathrm{Pn}$ and $\mathrm{Sn}$ beneath the Himalayan Arc and Tibetan Plateau - Possible Evidence for Underthrusting of Indian Continental Lithosphere beneath Tibet // Geology. 1982. Vol. 10. P. 179-185.

17. Barron J., Priestley K. Observations of frequency-dependent S-n propagation in Northern Tibet // Geophysical Journal International. 2009. Vol. 179. P. 475-488. https://doi.org/10.1111/j.1365-246X 18. Burtman V.S., Skobelev S.F., Molnar P. Late Cenozoic slip on the Talas-Ferghana fault, the
Tien Shan, Central Asia // Geological Society of America Bulletin. 1996. Vol. 108. P. 1004-1021.

19. Bosboom R., et al. Linking Tarim Basin sea retreat (west China) and Asian aridification in the late Eocene // Basin Research. 2013. Vol. 26. P. 1-20.

20. Sun J.M., Windley B.F., Zhang Z., Fu B., $\mathrm{Li} S$. Diachronous seawater retreat from the southwestern margin of the Tarim Basin in the late Eocene // Journal of Asian Earth Sciences. 2016. Vol. 116. P. 222-231.

21. Fu B., Ninomiya Y., Guo J. Slip partitioning in the northeast Pamir-Tian Shan convergence zone // Tectonophysics. 2010. Vol. 483. P. 344-364. https://doi.org/10.1016/j.tecto.2009.11.003

22. Sobel E.R., Schoenbohm L.M., Chen J., Thiede R., Stockli D.F., Sudo M., et al. Late MiocenePliocene deceleration of dextral slip between Pamir and Tarim: Implications for Pamir orogenesis // Earth and Planetary Science Letters. 2011. Vol. 304. P. 369-378. https://doi.org/10.1016/j.epsl.2011.02.012

23. Thompson J.A., Burbank D.W., Li T., Chen J., Bookhagen B. Late Miocene northward propagation of the northeast Pamir thrust system, northwest China // Tectonics. 2015. Vol. 34. P. 510534. https://doi.org/10.1002/2014TC003690

24. Sun J.M., Liu W., Liu Z., Deng T., Windley B.F., Fu B. Extreme aridification since the beginning of the Pliocene in the Tarim Basin, western China II Palaeogeography, Palaeoclimatology, Palaeoecology. 2017. Vol. 485. P. 189-200. https://doi.org/10.1016/j.palaeo.2017.06.012

25. Liu W.G., Liu Z., An Z., Sun J., Chang H., Wang N., et al. Late Miocene episodic lakes in the arid Tarim Basin, western China // Proceedings of the National Academy of Sciences of the United States of America. 2014. Vol. 111. P. 16292-16296. https://doi.org/10.1073/pnas.1410890111

\section{Authorship criteria / Критерии авторства}

Junmeng Zhao, Peizhen Zhang, Xiaohui Yuan, Weijun Gan, Jimin Sun, Tao Deng, Robert van der Hilst, Xiankang Zhang, Hongbing Liu, Xiaoping Yang, Maodu Yang, Qiang Xu, Heng Zhang, Gong Deng, Changhui Ju, Jiyang Lin, Jiwen Teng are the authors of the article, hold equal copyright and bear equal responsibility for plagiarism.

Чжао Цзюньмэн, Чжан Пэйчжэнь, Юань Сяохуй, Гань Вэйцзюнь, Сунь Цзиминь, Дэн Тао, ван дер Хилст Р., Чжан Сянькун, Лю Хунбин, Ян Сяопин, Ян Маоду, Сюй Цян, Чжан Хэн, Дэн Гун, Цзюй Чанхуй, Линь Цзиян, Тэн Цзивэнь написали статью, имеют равные авторские права и несут одинаковую ответственность за плагиат.

\section{Responsibility for plagiarism / Конфоликт интересов}

The authors declare that there is no conflict of interests regarding the publication of this article. Авторы заявляют об отсутствии конфоликта интересов.

All authors have read and approved the final version of this manuscript.

Все авторы прочитали и одобрили окончательный вариант рукописи. 


\section{Information about the authors / Сведения об авторах}

Junmeng Zhao,

Key Laboratory of Continental Collision and Plateau Uplift,

Institute of Tibetan Plateau Research, Chinese Academy of Sciences,

Beijing 100085, China

$\triangle$ e-mail: zhaojm@itpcas.ac.cn

Чжао Цзюньмэн,

Главная лаборатория континентальной коллизии и подъема Плато,

Институт изучения Тибетского плато, Китайская академия наук,

100085 , г. Пекин, Китай,

$\triangle$ e-mail: zhaojm@itpcas.ac.cn

\section{Peizhen Zhang,}

School of Earth Science and Geological Engineering,

Sun Yet-sen University,

Guangzhou 510275, China

Чжан Пэйчжэнь,

Школа наук о Земле и геологического инжиниринга,

Университет Сан Ейт-сен,

510275, г. Гуанджоу, Китай

Xiaohui Yuan,

Deutsches GeoForschungsZentrum,

Potsdam 14473, Germany

Юань Сяохуй,

Немецкий ГеоФоршунгЦентр,

14473 , г. Потсдам, Германия

\section{Weijun Gan,}

Institute of Geology of China Earthquake Administration,

Beijing 100029, China

Гань Вэйцзюнь,

Институт геологии Сейсмологического бюро Китая,

100029 , г. Пекин, Китай

\section{Jimin Sun,}

Institute of Geology and Geophysics, Chinese Academy of Sciences,

Beijing 100029, China

Сунь Цзиминь,

Институт геологии и геофизики, Китайская академия наук,

100029, г. Пекин, Китай

\section{Tao Deng,}

Key Laboratory of Vertebrate Evolution and Human Origins,

Institute of Vertebrate Paleontology and Paleoanthropology, Chinese Academy of Sciences,

Beijing 100044, China

\section{Дэн Тао,}

Главная лаборатория эволюции позвоночных и происхождения человека,

Институт позвоночных, палеонтологии и палеоантропологии, Китайская академия наук, 100044, г. Пекин, Китай

\section{Robert van der Hilst,}

Massachusetts Institute of Technology,

Cambridge 02139, Massachusetts, United States of America

$\triangle$ e-mail: hilst@mit.edu

Ван дер Хилст Роберт,

Массачусетский технологический институт,

02139, г. Кембридж, штат Массачусетс, Соединенные Штаты Америки

$\triangle$ e-mail: hilst@mit.edu 


\section{Xiankang Zhang,}

Center for Geophysical Exploration of China Earthquake Administration, Zhengzhou 450002, China

\section{Чжан Сянькун,}

Центр геофизических исследований Сейсмологического бюро Китая, 450002, г. Чжэнчжоу, Китай

\section{Hongbing Liu,}

Key Laboratory of Continental Collision and Plateau Uplift, Institute of Tibetan Plateau Research, Chinese Academy of Sciences, Beijing 100085, China

\section{Лю Хунбин,}

Главная лаборатория континентальной коллизии и подъема Плато, Институт изучения Тибетского плато, Китайская академия наук, 100085, г. Пекин, Китай

\section{Xiaoping Yang,}

Institute of Geology of China Earthquake Administration,

Beijing 100029, China

\section{Ян Сяопин,}

Институт геологии Сейсмологического бюро Китая, 100029 , г. Пекин, Китай

\section{Maodu Yang,}

Key Laboratory of Continental Collision and Plateau Uplift, Institute of Tibetan Plateau Research, Chinese Academy of Sciences, Beijing 100085, China

\section{Ян Маоду,}

Главная лаборатория континентальной коллизии и подъема Плато, Институт изучения Тибетского плато, Китайская академия наук, 100085, г. Пекин, Китай

\section{Qiang Xu,}

Key Laboratory of Continental Collision and Plateau Uplift, Institute of Tibetan Plateau Research, Chinese Academy of Sciences, Beijing 100085, China

\section{Сюй Цян,}

Главная лаборатория континентальной коллизии и подъема Плато, Институт изучения Тибетского плато, Китайская академия наук, 100085 , г. Пекин, Китай

\section{Heng Zhang,}

Key Laboratory of Continental Collision and Plateau Uplift, Institute of Tibetan Plateau Research, Chinese Academy of Sciences, Beijing 100085, China

\section{Чжан Хэн,}

Главная лаборатория континентальной коллизии и подъема Плато, Институт изучения Тибетского плато, Китайская академия наук, 100085, г. Пекин, Китай

\section{Gong Deng,}

Key Laboratory of Continental Collision and Plateau Uplift, Institute of Tibetan Plateau Research, Chinese Academy of Sciences, Beijing 100085, China

\section{Дэн Гун,}

Главная лаборатория континентальной коллизии и подъема Плато, Институт изучения Тибетского плато, Китайская академия наук, 100085 , г. Пекин, Китай 


\section{Changhui Ju,}

Key Laboratory of Continental Collision and Plateau Uplift,

Institute of Tibetan Plateau Research, Chinese Academy of Sciences,

Beijing 100085, China

Цзюй Чанхуй,

Главная лаборатория континентальной коллизии и подъема Плато,

Институт изучения Тибетского плато, Китайская академия наук,

100085, г. Пекин, Китай

\section{Jiyang Lin,}

Center for Geophysical Exploration of China Earthquake Administration, Zhengzhou 450002, China

Линь Цзиян,

Центр геофизических исследований Сейсмологического бюро Китая, 450002, г. Чжэнчжоу, Китай

\section{Jiwen Teng,}

Institute of Geology and Geophysics, Chinese Academy of Sciences,

Beijing 100029, China

Тэн Цзивэнь,

Институт геологии и геофизики, Китайская академия наук, 100029 , г. Пекин, Китай 